УДК 2-6:930.85:477
Віта Титаренко

\title{
ТЕОРЕТИЧНІ Й ПРАКТИЧНІ ВИМІРИ «УКРАЇНСЬКОГО СВІТУ»: МІСЦЕ ТА РОЛЬ РЕЛІГІЇ
}

\author{
Vita Tytarenko \\ THEORETICAL AND PRACTICAL DIMENSIONS \\ OF THE "UKRAINIAN WORLD": PLACE AND ROLE OF RELIGION
}

Анотація. В статті розглядається питання онтологіі украӥнського соціуму $b$ контексті потениійного його виходу із стану сингулярності - він (соиіум) має шанс перетворитися на щуось позитивно інше, або так $i$ залишитися у стані радикального збурення із суттєво зміненим порядком речей, явиш, очікувань, сподівань. Цей процес характеризується наступною контроверсійністю: 1) наявністю високого ризику деструктивних змін, які мають релігійну основу; 2) наявністю потенціалу конструктивних змін, досвіду, накопиченого та апробоВаного самою історичною присутністю релігї.

Автор пропонує (з фрілософсько-релігієзнавчих позиціӥ) пошук життєздатних і емпірично дієвих кониептів, спроможних об'єднати громадян крайни (у їх етнічній, культурній, релігійній тощуо багатоманітній ідентичності) у прагненні вивести український соиіум із стану сингулярності в новій якості, з перспективами позитивних змін.

В статті аналізуються окремі теоретичні аспекти поняття "Український світ», яке стає актуальним в середовищі релігієзнавиів i иого співвіднесеність з поняттями «нація», «украӥнська нація», «етнічна нація», «громадянська (політична) нація», «національна ідея», «національна держава» тощуо. В широкому розумінні «Украӥнський світ» може розглядатися як 
В. Титаренко. Теоретичні й практичні виміри «Українського світу»... простір єднання, співставний із загальнонаціональною ідентичністю, де індивід ототожнює себе з певними символами, цінностями, історією, територією, культурою, а також з державними та правовими інституиіями, політичними ӥ економічними інтересами. Таке розуміння концепту "Украӥнський сbіт» логічно виводить нас на необхідість аналізу практичної иоого складової. Послуговуючись даними сочіологічних опитувань, статистичними даними, інтерв'ю, прикладами діяльності релігійних організацій $i$ об'єднань, автор аналізує місце релігї $b$ иъвому просторі єднання, ї̈ потенціал, ризики, виклики.

Висновується, що «Украӥнський світ» як простір єднання може $і$ здатен формуватися за умов: 1) адекватної $i$ зваженої політики з боку, перш за все, украӥнської держави відповідно до Конституиії, чинного законодавства, без преферениій для окремих конфесій (особливо на місияя), як шлях фрормування довіри до органів влади з боку конфесій; 2) розуміння $i$ усвідомлення 3 боку представників церков $і$ релігійних організацій своєї відповідальності перед українським суспільством, базування на універсальних загальнолюдських ијнностях, здатних об'єднати українців, та реалізація цих иінностей через практичну діяльність в суспільстві.

Ключові слова: сингулярність, «Український світ», релігія, ризики, ідентичність, конфесія, нація, иінності.

Abstract. The article considers the issue of ontology of Ukrainian society in the context of its potential exit from the state of singularity. It (society) has a chance to turn into something positively different, or to remain in the state of radical perturbation, with significantly changed order of things, phenomena, expectations and hopes. This process is characterized by the following controversy: 1) the presence of a high risk of destructive changes that have a religious basis; 2) the presence of the potential for constructive changes and the experience accumulated and tested by the very historical presence of religion. 
The author proposes search for viable and empirically effective concepts that can unite the citizens of the country in their ethnic, cultural, religious, etc. diverse identity in an effort to bring out Ukrainian society from the state of singularity with prospects for positive changes.

The article analyzes some theoretical aspects of the concept of "Ukrainian world", which becomes relevant among religious scholars and its correlation with the concepts of "nation", "Ukrainian nation", "ethnic nation", "civil (political) nation", "national idea", "nation state", etc. In a broad sense, the "Ukrainian world" can be seen as a space of unity, comparable to a national identity, where the individual identifies himself/herself with certain symbols, values, history, territory, culture, as well as with state and legal institutions, political and economic interests. This understanding of the concept of "Ukrainian world" logically leads us to the need to analyze its practical component. Using various data from opinion polls, statistics, interviews, examples of religious organizations and associations activities, the author analyzes the position of religion in this space of unity, its potential, risks, challenges.

It is concluded that the "Ukrainian world" as a space of unity can be formed under the conditions of: 1) adequate and balanced policy pursued, first of all, by the Ukrainian state in accordance with the Constitution, current legislation, without any preferences for individual denominations (especially on the ground), as a way to build trust in the authorities by confessions; 2) understanding and awareness of churches and religious organizations representatives their responsibility to Ukrainian society, based on universal values, that can unite, and the realization of these values through practical activities in society.

Key words: singularity, "Ukrainian world", religion, risks, identity, confession, nation, values.

Постановка проблеми. Події зими 2013-2014 років, анексія Криму і війна на Донбасі спричинили перехід 
В. Титаренко. Теоретичні й практичні виміри «Українського світу»...

українського соціуму у той стан, який обгрунтовано вважається сингулярним. Минаючи широкі астрофізичні та математичні пояснення цього терміну, акцентуємо увагу на тому, що з поняттям сингулярності часто пов'язують ідею про неможливість передбачення майбутнього стану тієї чи іншої системи. Якщо ми говоримо про український соціум, то в категоріях сингулярності він перебуває в стані радикального збурення, із суттєво зміненим порядком речей, явищ, очікувань і сподівань, і має шанс як перетворитися на щось позитивно інше, так і залишитися у вимушено знайденому стані. Зважаючи на істотні зовнішні ризики як військово-політичні та територіально-просторові, так i внутрішні, які 3 особливою гостротою проявляються у функціонуванні державних інститутів, варто об'єктивно визнати, що ризик деструктивних змін в країні є досить високим. Поза тим, важливо переконувати, що Україна не позбавлена й потенціалу конструктивних змін.

Мета статті полягає в прагненні філософсько-релігієзнавчого пошуку життєздатних і емпірично дієвих концептів, спроможних об'єднати громадян країни і вивести український соціум із стану сингулярності в новій якості. До завдань статті віднесено; 1) аналізування теоретичних та практичних вимірів «Українського світу» як простору єднання; 2) визначення місця та ролі у ньому релігії.

Виклад основного матеріалу. Українська інтелектуальна еліта усвідомлює (а чи ж, змушена усвідомлювати), що суспільство вже не задовольняють логічні пояснення подій, що відбуваються. Час і ситуація сингулярності вимагають життєздатних і емпірично дієвих концептів, спроможних об'єднати громадян країни (у їх етнічній, культурній, релігійній тощо багатоманітній ідентичності) і вивести український соціум із стану сингулярності в новій якості, 
що забезпечить йому позитивні зміни 3 перманентним зростанням якості життя громадян. Звичайно, і це варто підкреслити, в українській гуманітаристиці напрацьовано потужний рівень осмислення фундаментальних питань об'єднавчої направленості - національна та етнічна ідентичність (М.Степико, М.Рябчук, В.Лісовий, Я.Верменич, Б.Петруньок та ін.), український національний характер, українська ментальність (Ю.Руденко, С.Хрипко та ін.), національна ідея (від М.Драгоманова, М.Грушевського, В.Липинського - до сучасників: А.Свідзинського, М.Михальченка, О.Забужко, О.Донія, О.Кочеткова та ін). Окрема тематика співвідношення національного і релігійного в українському соціумі розроблялася науковцями Відділення релігієзнавства Інституту філософії імені Г.С.Сковороди НАН України, зокрема у колективних монографіях «Релігія і нація в суспільному житті України» і світу» (2006), «Функціональність релігії: український контекст» (2011), «Свобода релігії і національна ідентичність» (2002), «Релігійні ідентичності в їх сутності і конфесійних виявах: український контекст» (2021).

Практичними кроками, спрямованими на консолідацію українського соціуму, можна вважати проведення циклу Національний круглих столів «В єдності сила», одних з яких був присвячений напрямку «Віра і релігія». Саме релігійна складова як чинник розбудови українського світу в іï можливостях, реаліях, перспективах і викликах постає об'єктом наших рефлексій. Можна погодитися з відомим політичним аналітиком О.Кочетковим у його твердженні, що «відсутність чіткої об'єднувальної функції не дозволяє вважати ані віру, ані мову базисом для виникнення національної ідеї всієї України» [Кочетков 2011: 16]. I дійсно, маємо приклади, коли мова чи релігія не були вираз- 
В. Титаренко. Теоретичні й практичні виміри «Українського світу»...

никами основної приналежності до нації: Швейцарія й Канада мають різні мови, США і Німеччина мають різні релігії. Але продовження думки О. Кочеткова, з якою ми також погоджуємося, засвідчує визнання важливості, хоча й не вичерпності функціоналу мови й релігії [Там само]. На підтвердження думки можемо зауважити, що, наприклад, порушення рівноваги між національною і релігійною ідентичністю, коли релігійна виявляється сильнішою - вона здатна стати фактором послаблення держави, суспільства.

Чи є розділеність соціуму кризою? Поза сумнівом. Але чи, 3 необхідністю, це мусить бути катастрофою питання відкрите. В сучасному глобалізованому світі на політичній мапі проблематично і навіть утопічно віднайти абсолютно гомогенну у всіх сферах країну. Поділи відбуваються за різними ознаками - політичними, соціальними, в тому числі й релігійними. Але, як зазначає відомий філософ, етнолог, спеціаліст у сфері національної безпеки М. Степико, «у таких суспільствах завдяки політичним і державним компромісам зберігається національна єдність» [Степико 2011: 101]. Як ілюстрація компромісів - Бельгія, Великобританія (з Північною Ірландією), Канада, Мексика, Індія (з їі мусульманською складовою), Іспанія (з басками), Італія і навіть Росія. Важливим залишається усвідомлення, що об'єднання, консолідація соціуму можуть бути ситуативними - 3 різним походженням, спрямуванням і тривалістю [Там само]. Принагідно згадаємо безпрецедентний приклад феномену зародження громадянської церкви в період Майданних подій 2013-2014 рр., коли конфесійна приналежність відійшла на задній план, важливішим поставало завдання відстоювання громадянських прав і свобод. Але роль релігійного фактору не була однозначно консолідуючою: поряд з процесами організації й самоорга- 
нізації відбувалися й процеси дезорганізації і дезінтеграції. В книзі Л. Филипович та О. Горкуші «Майдан і Церква» представлені релігійні документи, звернення, заклики релігійних лідерів до народу і до влади, неофіційні висловлювання й коментарі звичайних віруючих та пасторів, які зафіксували хронологію тих подій та реакцію і місце в них українських Церков у їх конфесійній різноманітності [Майдан 2014].

Розгортаючи розмірковування на означену тему, ми 3 необхідністю маємо схарактеризувати ще одне ключове поняття - «Український світ». Утримуючи в собі полісемантичність, це поняття означає: 1) в українознавстві - когнітивну метафору, асоціативно пов' язану з українською культурою; 2) в філософії - онтологічну реальність, узагальнену за певними ознаками (соціокультурними, етнонаціональними, суспільно-історичними, геоекономічними, геополітичними) в цілісність [Український]. В працях різних авторів існують дещо відмінні основи «українського Світу»: духовність і держава, українська культура і мова, національна економіка і розвинена соціальна сфера, українська наука та технології тощо (українознавство). Останнім часом це поняття активно обговорюється в середовищі релігієзнавців. Із виступу О. Горкуші на методологічному семінарі ми можемо зафіксувати його наступну дефініцію: ««Український світ» - це висловлений українською історіографією засобами української мови-ментальності-культури-традицій в українському ціннісно-смисловому універсумі (аксіологічний вимір) подійно-життєвий локус, який сприймається українською нацією (історично-самосвідомим суб'єктом) як освоєний дім буття... «Український» світ і в релігійних вимірах визначатиметься українським світоглядом та формулюватиметься українською мовою, куль- 
В. Титаренко. Теоретичні й практичні виміри «Українського світу»... турою, історіографією, сучасною подійною дійсністю» [Горкуша 2021]. Для нас це визначення поєднує цілу низку усталених в українській гуманітаристиці понять, зокрема, нація, українська нація, етнічна нація, громадянська (політична) нація, національна ідея, національна держава тощо. В широкому розумінні «Український світ» може розглядатися як простір єднання, співставний із загальнонаціональною ідентичністю, де індивід ототожнює себе 3 певними символами, цінностями, історією, територією, культурою, а також, що $є$ важливим і для нашого подальшого викладу - 3 державними та правовими інституціями, політичними й економічними інтересами. Причому прийняття своєї тотожності індивідом відбувається й на емоційному, чуттєвому рівні, що дозволяє нам розглядати «Український світ» як Гемайншафт (В. Тьонніс) життєвим організмом, здатним, за словами дослідниці ідентичності націй М. Гібернау, «створити сентиментальний зв'язок і чуття належності серед своїх членів» [Гібернау 2021: 237]. В цьому контексті і в цьому зв'язку ми здатні краще зрозуміти й релігійний Гемайншафт як певне родинне, домашнє, взаємосолідарне, затишне співіснування.

Ми свідомі того, що, розмірковуючи наступним чином, можемо підпасти під дію принципу логіки, відомого як лезо Окками, який сформульований як методологічний принцип: «Те, що можна пояснити за допомогою меншого, не варто виражати за допомогою більшого». Іншими словами - не варто примножувати сутності. Також існує засторога, що «Український світ» ризикує стати калькою концепції «Руського міра», який є політичною концепцією, де релігія та культура стають заручниками політичних та геополітичних цілей. Таку думку, зокрема, обстоював в інтерв'ю о. Андрій Зелінський (радник Глави УГКЦ з питань 
стратегії комунікації, заступник керівника Департаменту військового капеланства) [Зелінський 2021]. Однак, відповідне пояснення можемо віднайти в праці М. Степико, який зазначає, що «в російському науковому дискурсі (імперському за всіх часів) актуалізація етнічної проблематики кидає виклик цілісності та єдності російської нації, яка за ії етнічної строкатості потребувала саме конструктивістських «скреп» iї єдності (самодержавие, православие, народность)» [Степико 2020: 20], але «для більш-менш моноетнічних націй, таких як українська, важливою $є$ «вкоріненість» нації і пріоритет етнотериторіального устрою державного життя» [Там само]. Тобто, поняття «Український світ» - це і реалізація соціального змісту національної ідеї, i використання об'єднувальної ролі державної мови, спільної історичної пам'яті, демократизація державної влади, культурних цінностей, умовно «ведення спільного господарства» тощо. I наше завдання (як уже зазначалося) - проаналізувати місце релігії в цьому просторі єднання, ії потенціал, ризики, виклики.

Україна не раз поставала прикладом поліконфесійного співжиття ії громадян. Відомий соціолог Х. Казанова, зазначав: «Україна - єдина європейська країна, яка наближається до американської моделі релігійного деномінаціоналізму» [Казанова 2019: 9]. Ця модель гуртувалася як на ліберальній законодавчій базі у сфері релігії, так і виразному плюралізмі основних християнських конфесій, жодна з яких не могла претендувати на гегемонію в загальноукраїнському масштабі [Там само]. За даними Звіту про мережу релігійних організацій в Україні станом на 1 січня 2020 (поданого Департаментом у справах релігій, національностей і меншин), нараховується 36796 релігійних організацій, які презентують понад 100 релігійних напрям- 
В. Титаренко. Теоретичні й практичні виміри «Українського світу»...

ків. В свою чергу, соціологічний моніторинг стану і тенденцій розвитку релігійності українського суспільства, здійснюваний Центром О. Разумкова, засвідчує досить високий рівень релігійності у 2020 році - 67,9\%. Найвищий рівень релігійності був зафіксований у 2014 році і становив 76\% [Особливості 2020: 3]. Важливим консолідуючим фактором може слугувати досить високий рівень толерантності до сповідування різних релігій в українському суспільстві. Громадяни в більшості вважають, що «будь-яка релігія, яка проголошує ідеали добра, любові, милосердя і не загрожує існуванню іншої людини, має право на існування» (57,2\%) або «всі релігії мають право на існування як різні шляхи до Бога» $(24,5 \%)$; і лише $22 \%$ опитаних підтримали твердження «істинною є лише та релігія, яку я сповідую» (7\%), або «право на існування мають лише традиційні для нашої країни релігії» (15\%); сума цих відповідей практично не мінялася, коливаючись у діапазоні 2022\%. Загалом, переважно позитивним залишається ставлення громадян до найпоширеніших в Україні релігій i релігійних течій, до менш поширених і відомих - переважно байдужим; негативне ставлення до жодної з релігій чи релігійних течій не переважає [Там само].

Попри наступні показники, в контексті релігійної ідентичності українства, мабуть, не варто шукати підвалини консолідування «українського світу» на засадах конфесійної гомогенності. Але варто визначити позитив у тому, що українське суспільство не відчуває суттєвих перешкод для побудови простору взаємодії, саме з цієї ж причини поліконфесійності, хоча, об'єктивність вимагає тримати в пам'яті прецеденти, коли саме поліконфесійнійсть (наприклад, у ії православному вимірі) поставала причиною дезінтеграційних процесів в українському су- 
спільстві. На жаль, це напряму пов'язано 3 іншою проблемою - конфліктом кількох ідеологій управління країною та груп, які їх обстоюють, використовуючи релігійний чинник. Політизація релігійного життя посилює негативні прояви й перешкоджає консолідації українського соціуму. За визначенням С. Здіорука, найчастіше конфліктність міжконфесійних і міжцерковних відносин обумовлюються майновими й територіальними претензіями, атмосферою конкуренщіï, різновекторними політичними симпатіями суб'єктів конфлікту [Здіорук 2011: 96]. Тобто, релігія в ії інституалізованих формах не тільки стає віддзеркаленням ситуації в суспільстві, але і сама є втягнутою в ці процеси.

Контент аналіз інтерв'ю, зустрічей з представниками різних конфесій України, проведених в рамках інформаційно-методологічного семінару «Релігія в особах»1, засвідчує, що, в першу чергу, релігія орієнтує своїх вірян, які є й громадянами України, на утвердження універсальних загальнолюдських цінностей, центральною серед яких є любов. Таку позицію озвучують, зокрема, представники ПЦУ, УГКЦ, РКЦ, низки протестантських напрямків, грунтуючись на біблійній істині, що «Бог є любов». Втілення любові до Бога через любов до людини, конкретизується в конфесійних соціальних наративах в такі цінності, як свобода і гідність, справедливість, соборність. Реалізація цих цінностей в «українському світі» як просторі єднання відкриває перспективи переходу на інший рівень розвитку українського соціуму - від національної та вузької релі-

1 Семінар проводиться на базі відділу (відділення) релігієзнавства Інституту філософії імені Г.С.Сковороди НАН України та кафедри релігієзнавства Київського національного університету імені Тараса Шевченка протягом кінця 2020 - початку 2021 pр. Отримано з вебсайт: https://www.youtube.com/watch?v=9yybGwL1Uug\&list=PLD4ff6oXooZenZ7Ur6PFn5pWfAYKSdN9\&index $=13$ 
В. Титаренко. Теоретичні й практичні виміри «Українського світу»...

гійно-конфесійної ідентичності - до громадянської, державотворчої, що реалізуватиметься в прагненні інтегрувати християнські принципи у будову державності. Важливим в цьому контексті постає взаємоузгодження релігійної i громадянської складової, вихід українського соціуму на ті якісні зміни, які дозволять формування в межах «Українського світу» сфери самовиявлення і самоорганізації вільних громадян для відстоювання інтересів, прав і свобод людини. Щонайперше, маємо до того історичне підгрунтя, про яке М. Степико говорить, що «українці завжди були здатні на добровільне об'єднання в самоорганізовані та самокеровані структури і братства, артілі, гуртки, кооперативи, товариства, корпорації. Взагалі українська душа (всупереч трагічному історичному досвіду) демонструє величезну життєлюбність і життєздатність з орієнтацією на сьогодення» [Степико 2011: 270]. Прикладами таких громадських об'єднань в релігійній сфері є ВРЦіРО (Всеукраїнська рада Церков і релігійних організацій), ВРРО (Всеукраїнська рада релігійних об'єднань), Рада Євангельських протестантських церков України, Нарада представників християнських Церков України, Всеукраїнська Ради Християнських Церков, Рада представників Духовних управлінь і центрів мусульман України та інші, які конституюються і сьогодні. Однак, в діяльності деяких із названих організацій, попри результативність та позитиви, присутні й такі ризи, як узурпування повноважень і «вибірковість» членства, прагнення диктувати «порядок денний», підміняти функції державних органів тощо. Отже, попри наявний потужний потенціал, високу довіру в суспільстві вплив конфесій на формування громадянської складової в країні не є однорідним і достатньо ефективним Як ми вже зазначали вище, релігія утримує в собі як потенціал кон- 
солідуючого фактора, так і конфліктогенний потенціал. Рік 2004, а потім і 2013-2014 - продемонстрували здатність релігії як згуртовувати соціум, впливаючи на державну владу у прагненні відстояти громадянські права, так і здатність релігійних організацій виступати суб'єктом опозиції до влади.

Зрозуміло, що консолідаційна роль релігії посилюється в кризових ситуаціях соціальних, політичних потрясінь. Але потенщіал конфесій - набагато ширший і здатен опановувати простір єднання в сферах, близьких кожній конфесії і кожному громадянину, незалежно від його віросповідних принципів. В одному з виступів єпископ РКЦ Станіслав Широкорадюк зазначав, що об'єднуючим, спільним началом для конфесійного гуртування має бути мораль, моральна поведінка - як кліру, так і мирян, що потрібно прищеплювати і чому потрібно вчити [Широкорадюк 2021]. До простору єднання він відносить і сферу релігійної освіти, підкріплюючи свою позицію прикладами спільних освітніх програм католицьких та православних священиків (є приклади співпраці п'ятидесятницької i харизматичної конфесій, православної і мормонської церков). Не полишає своєї актуальності дієвість спільних соціально-харитативних програм. Великим об'єднавчим потенціалом для католиків, православних і протестантів залишається військове капеланство, особливо запотребоване в умовах російської агресії на Сході країни.

Тому, на нашу думку, важливо артикулювати «точки росту» для конфесій України як основу якісних змін на шляху консолідації українського соціуму. Ці «точки росту» становлять собою прописані цілі, що лягають в основу міжконфесійного діалогу і співпраці: практика військового i медичного капеланства, доопрацювання законодавчих 
В. Титаренко. Теоретичні й практичні виміри «Українського світу»... ініціатив (законопроекти «Про військове капеланство», «Про медіа», «Про захист персональних даних» тощо), спрощення механізму оформлення гуманітарної допомоги та ін.

Чи не найголовнішим в процесі формування «Українського світу» як простору єднання постає усвідомлення його не як чогось усталеного і назавжди фіксованого. Це, в першу чергу, процес, який вимагає спільних суспільногромадянських зусиль для підтримки його у тих формах, які постають запотребованими нині українським суспільством. Важлива роль в цьому процесі відводиться й релігії в багатоманітті іï конфесійних виявів. Відданість українців заповідям християнської віри (попри світський вектор розвитку держави) й нині підтверджується соціологічними опитуваннями, статистичними даними, формами активності і дієвості самих конфесій, їх включеністю в суспільні процеси. Але йдеться про ширше коло конфесій України - мусульман, іудеїв, Віру Бахаї, сучасне українське рідновірство тощо, які є вагомою складовою українського суспільства.

Висновок. Узагальнюючи вищевикладене, зазначимо, що важливість цінностей свободи і демократії, гідності й справедливості підтримуються й поділяються практично всіма конфесіями України, що може й має бути використано як підгрунтя гуртування українського соціуму.

«Український світ» як простір єднання може і здатен формуватися за умов: 1) адекватної і зваженої політики 3 боку, перш за все, української держави - відповідно до Конституції, чинного законодавства, без преференцій для окремих конфесій (особливо на місцях), як шлях формування довіри до органів влади з боку конфесій; 2) розуміння і усвідомлення з боку представників релігійних 
організацій своєї відповідальності перед українським суспільством, базування на універсальних загальнолюдських цінностях, здатних об'єднати українців та реалізація означених цінностей через свою практичну діяльність в суспільстві.

\section{Список літератури}

Гібернау, М. (2012) Ідентичність націй. К.: Темпора. 304 с.

Горкуша, О. (2021) Концепт «Український світ» як когнітивний ідентифікатор життєвого простору сучасних українців (філософсько-релігієзнавчий аналіз). Виступ на інформаційнометодологічному семінарі у відділі (відділенні) релігієзнавства Інституту філософії імені Г.С.Сковороди НАН України. URL: https://www.facebook.com/oksana.gorkusa/posts/395320048805209 2?comment_id=3955793404459467\&reply_comment_id=395582007779 0133\&notif_id=1614878695277947\&notif_t $=$ mentions_comment\&ref=n otif

Здіорук, С. (2011) Релігійні цінності у стратегії демократичного поступу української нації в новітню добу. В 20 років незалежності Украӥни: здобутки, втрати і стратегї майбутнъого: мат-ли ХІ наук.-практ. конф. К. : НАДУ. С. 89-107.

Зустріч-інтерв'ю $з$ єпископом Станіславом Широкорадюком (2021). Інформаційно-методологічний семінар «Релігія в особах». Отримано з вебсайт:

https:/ / www.youtube.com/watch?v=9yybGwL1Uug\&list=PLD4ff6o XooZe-nZ7Ur6PFn5pWfAYKSdN9\&index=13

Зустріч-інтерв'ю з о.Зелінським (2021). Інформаційно-методологічний семінар «Релігія в особах». URL: https:/ / www.youtube.com/watch?v=9yybGwL1Uug\&list=PLD4ff6o XooZe-nZ7Ur6PFn5pWfAYKSdN9\&index=13

Казанова, Х. (2019). Релігія в сучасному світі: плюралізм, секуляризація, глобалізація /переклад з англ. Р.Скакуна. Львів: Видавництво УКУ. 348 с.

Кочетков, О. (2019) Трансформація національної ідеї: що важливіше - ідея чи саме трансформація? В Трансформація української національної ідеї / упоряд. О. Доній. К. : Наш формат. 464 с. 
В. Титаренко. Теоретичні й практичні виміри «Українського світу»...

Майдан і Церква: хроніка подіӣ та експертна оцінка (2014). Упорядники Л.Филипович і О.Горкуша. К.: СаммитКнига. 656 с.

Особливості релігійного і иерковно-релігійного самовизначення громадян України: тенденції 2000-2020рр. (Інформаційні матеріали) (2020). Київ. 78 с.

Степико, М. (2011) Украӥнська ідентичність: феномен і засади формування. К. : НІСД. 336 с.

Степико, М. (2020) Українська ідентичність у глобалізованому cbimi. Х.: Майдан. 258 с.

«Український світ». URL:

https://uk.wikipedia.org/wiki/\%D0\%A3\%D0\%BA\%D1\%80\%D0\%B0 \%D1\%97\%D0\%BD\%D1\%81\%D1\%8C\%D0\%BA\%D0\%B8\%D0\%B9_\%D $1 \% 81 \% \mathrm{D} 0 \% \mathrm{~B} 2 \% \mathrm{D} 1 \% 96 \% \mathrm{D} 1 \% 82$

\section{References}

Gibernau, M. (2012) The identity of nations. K .: Tempora. $304 \mathrm{s.}$

Gorkusha, O. (2021) The concept of "Ukrainian world" as a cognitive identifier of the living space of modern Ukrainians (philosophical and religious analysis). Speech at the methodological seminar in the department (department) of religious studies of the GS Skovoroda Institute of Philosophy of the National Academy of Sciences of Ukraine. URL:

https:// www.facebook.com/oksana.gorkusa/posts/395320048805209 2?comment_id=3955793404459467\&reply_comment_id=395582007779 0133\&notif_id=1614878695277947\&notif_t $=$ mentions_comment\&ref=n otif

Zdioruk, S. (2011) Religious values in the strategy of democratic progress of the Ukrainian nation in modern times. In 20 years of independence of Ukraine: gains, losses and strategies of the future: mat-li XI scientific practice. conf. K.: NADU. Pp. 89-107.

Meeting-interview with Bishop Stanislav Shirokoradiuk (2021). Methodological seminar "Religion in persons". URL: https:/ / www.youtube.com/watch?v=9yybGwL1Uug\&list=PLD4ff6o XooZe-nZ7Ur6PFn5pWfAYKSdN9\&index=13

Meeting-interview with Fr. Zelinsky (2021). Methodological seminar "Religion in persons". Retrieved from: 
https:/ / www.youtube.com/watch?v=9yybGwL1Uug\&list=PLD4ff6o XooZe-nZ7Ur6PFn5pWfAYKSdN9\&index=13

Casanova, J. (2019). Religion in the modern world: pluralism, secularization, globalization. English translation by Skakun. Lviv: UCU Publishing House. 348 p.

Kochetkov, O. (2019) Transformation of the national idea: what is more important - the idea or the transformation? In Transformation of the Ukrainian national idea / order. O. Doniy. K .: Our format. $464 \mathrm{~s}$.

Maidan and Church: Chronicle of Events and Peer Review (2014). Compiled by L. Fylypovych and O. Horkusha. Kyiv: Summit Book. $656 \mathrm{p}$.

Peculiarities of religious and church-religious self-determination of citizens of Ukraine: tendencies of 2000-2020. (Information materials) (2020). Kyiev. 78 p.

Stepyko, M. (2011) Ukrainian identity: phenomenon and principles of formation. K.: NISD. $336 \mathrm{~s}$.

Stepyko, M. (2020) Ukrainian identity in the globalized world: Kh.: Maidan. 258 s.

"Ukrainian World". URL:

https://uk.wikipedia.org/wiki/\%D0\%A3\%D0\%BA\%D1\%80\%D0\%B0 \%D1\%97\%D0\%BD\%D1\%81\%D1\%8C\%D0\%BA\%D0\%B8\%D0\%B9_\%D $1 \% 81 \% \mathrm{D} 0 \% \mathrm{~B} 2 \% \mathrm{D} 1 \% 96 \% \mathrm{D} 1 \% 82$ 